\title{
Neonatal Sepsis due to Salmonella enteritidis from Colonized Breast Milk; A Case Report and Literature Review of Breast Milk-induced Neonatal Sepsis
}

\section{Anne Sütü Kaynaklı Salmonella enteritidis Sepsisi; Bir Olgu Sunumu ve Anne Sütü Kaynaklı Yenidog̃an Sepsislerinin Literatür Derlemesi}

\author{
Meltem KARABAY'(ID), Zahir ȘEHMUSOG̃LU'(IID), Hüseyin Agah TERZi(IiD), ibrahim CANER'(IID), \\ Mehmet KÖROG̃LU(IID)
}

\footnotetext{
${ }^{1}$ Clinic of Neonatology, Department of Pediatrics, Sakarya Training and Research Hospital, Sakarya, Turkey

${ }^{2}$ Department of Medical Microbiology, Sakarya Training and Research Hospital, Sakarya, Turkey
}

Cite this article as: Karabay M, Şehmusoğlu Z, Terzi HA, Caner I, Köroğlu M. Neonatal sepsis due to Salmonella enteritidis from colonized breast milk; a case report and literature review of breast milk-induced neonatal sepsis. FLORA 2021;26(2):323-7.

\section{ABSTRACT}

Breastfeeding is the most important source of infant nutrition. However, if the mother's milk is not obtained in a hygienic environment, it may be risky for the infant. In this article, a case of Salmonella enteritidis sepsis caused by breastfeeding was reported with reference to the literature.

Key Words: Breastfeeding; Human milk; Lactation; Salmonella enteritidis

ÖZ

Anne Sütü Kaynaklı Salmonella enteritidis Sepsisi; Bir Olgu Sunumu ve Anne Sütü Kaynaklı Yenidog̃an Sepsislerinin Literatür Derlemesi

Meltem KARABAY', Zahir ȘEHMUSOG̃LU', Hüseyin Agah TERZi², ibrahim CANER', Mehmet KÖROG̃LU²

\footnotetext{
'Sakarya Eg̃itim ve Araștırma Hastanesi, Çocuk Sag̃lıg̃ı ve Hastalıkları Anabilim Dalı, Neoanatoloji Klinig̃i, Sakarya, Türkiye

2 Sakarya Eg̃itim ve Araștırma Hastanesi, Tıbbi Mikrobiyoloji Anabilim Dalı, Sakarya, Türkiye
}

Anne sütü çocuk beslenmesinde en önemli kaynaktır. Ancak anne sütü hijyenik ortamda elde edilmezse çocuk için riskli olabilir. Bu yazıda anne sütünden kaynaklanan bir Salmonella sepsisinin oluşumu ve tedavisinin literatür eşliğinde raporlanması amaçlanmıştır. Anahtar Kelimeler: Emzirme; Anne sütü; Laktasyon; Salmonella enteritidis 


\section{INTRODUCTION}

Breastfeeding is universally the best food for infants. However, although rare, infections in mothers' milk have been reported. Breastfeeding in far from hygienic conditions could be an important source of infection ${ }^{[1]}$.

Breastfeeding-related infections that have been reported include the Hepatitis $\mathrm{B}$ virus, Мyсоbacterium tuberculosis, Cytomegalovirus, Human Immunodeficiency Virus (HIV), Herpes Simplex virus, Epstein-Barr Virus, West Nile virus, Listeria, Brucella, and Streptococcus agalactiae. Salmonella infections associated with breast milk have also been reported ${ }^{[2]}$. Here, we report Salmonella transmission through breastfeeding and the resulting sepsis in the infant.

\section{CASE REPORT}

Our case was a female infant born by cesarean section and weighing $3150 \mathrm{~g}$ at 38 weeks' gestation as gravid 2, parity 2 from a 26-year-old woman. The infant was hospitalized in the neonatal intensive care unit with diarrhea and fever $\left(38^{\circ} \mathrm{C}\right)$ on the seventh postnatal day. Physical examination revealed a body weight of $2860 \mathrm{~g}$ (9\% weight loss), poor general condition, pale yellow mottled skin, delayed capillary refill time, decreased newborn reflexes, reduced skin turgor and tonus, decreased fontanel thickness, poor sucking, abdominal distention, and diffuse sensitivity on palpation. A respiratory rate of 50 breaths per min, pulse rate of 140 beats per minute and a decrease in the level of consciousness were seen.

Other physical examination findings were normal. There was not a positive feature in the personal and family history. Laboratory investigations were as follows: leukocyte count $11.7 \mathrm{~K} / \mathrm{L}$; hemoglobin $16.1 \mathrm{~g} / \mathrm{dL}$; platelet 382,000; CRP 64 $\mathrm{mg} / \mathrm{L}$; blood glucose $126 \mathrm{mg} / \mathrm{dL}$; urea $63.4 \mathrm{mg} /$ dl (17-43 mg/dL); creatinine $1 \mathrm{mg} / \mathrm{dL}$; sodium $129 \mathrm{mmol} / \mathrm{L}$; potassium $5 \mathrm{mmol} / \mathrm{L}$; chlorine 95 $\mathrm{mmol} / \mathrm{L}$; calcium $2,24 \mathrm{mmol} / \mathrm{L}$; phosphorus 2.48 $\mathrm{mmol} / \mathrm{L}$; alkaline phosphatase $178 \mathrm{IU} / \mathrm{L}$; total bilirubin $17.8 \mathrm{mg} / \mathrm{dL}$; direct bilirubin $1.1 \mathrm{mg} /$ $\mathrm{dL}$; alanine aminotransferase $55 \mathrm{IU} / \mathrm{L}$; aspartate aminotransferase $72 \mathrm{IU} / \mathrm{L}$; total protein $6.5 \mathrm{~g} / \mathrm{dL}$; albumin $4.3 \mathrm{~g} / \mathrm{dL}$; prothrombin time $11 \mathrm{sec}$; INR 0.93, and blood $\mathrm{pH} 7.29$.
Abdominal sonography signs were in the normal range. The amino acid profile and blood galactose level were normal. Stool microscopy was relevant: 1-2 leukocytes (40X magnification) were present in each site, the stool was colorless and blood was negative. Multiplex PCR for fecal adeno virus DNA and rotavirus RNA were negative (FTD bacterial and viral gastroenteritis panel, Fast Track Diagnostics Ltd., Luxembourg). Antigen testing of stool for Entamoeba histolytica and Giardia intestinalis (MonlabTest, Spain) was negative. Cerebro-spinal fluid culture and urine culture were negative.

Breast milk culture is not routinely performed in our unit. But in this patient, we were looking for a focus that could cause sepsis. For this reason, breast milk culture was also made in addition to many samples of the patient.

The patient was followed up in the neonatal intensive care unit, where intravenous hydration and total parenteral nutrition were started. Breastfeeding was terminated and open drainage was performed with an orogastric catheter. Parenteral piperacillin-tazobactam, vancomycin and pentoxifylline were initiated for sepsis. Salmonella enteritidis was grown in cultures (both the infant's blood cultures and the mother's breast milk culture). As a result of serogrouping with specific antisera, it was determined that the serotype of both bacteria was Salmonella enteritidis $(9,12, \mathrm{gm} ;-)$. The antibiotic resistance patterns of $S$. enteritidis for both cultures are shown in Table 1. Salmonella from both breast milk culture and infant was sensitive to piperacillin-tazobactam, so piperacillin-tazobactam treatment was continued and vancomycin was stopped. The patient's total bilirubin was below 18 $\mathrm{mg} / \mathrm{dL}$; therefore, phototherapy was performed. The patient responded positively to the treatment. Metabolic acidosis in her blood gas improved, and the acute phase reactants started to regress. Blood CRP value decreased after 48 hours; $36 \mathrm{mg} / \mathrm{L}$ after 72 hours $11 \mathrm{mg} / \mathrm{L}$; and after 96 hours $<5 \mathrm{mg} / \mathrm{L}$ with therapy. Also, serum sodium level was normalized (135 meq/L) after 48 hours of therapy. Her fever dropped, and she recovered. On the third day of hospitalization, oral feeding was gradually increased by starting with formula milk. Treatment of the infant was stopped after 


\begin{tabular}{|c|c|c|}
\hline \multirow[b]{2}{*}{ Antibiotics } & \multicolumn{2}{|c|}{ Salmonella enteritidis } \\
\hline & Breast milk & Blood culture \\
\hline Amoxicillin/clavulanic acid & $S$ & $S$ \\
\hline Gentamicin & $\mathrm{R}$ & $\mathrm{R}$ \\
\hline Amikacin & $\mathrm{R}$ & $S$ \\
\hline Meropenem & $S$ & $S$ \\
\hline Piperacillin/tazobactam & $S$ & $S$ \\
\hline Ceftazidime & $S$ & S \\
\hline
\end{tabular}

14 days. The infant's mother was also treated with oral amoxicillin-clavulanate. After two weeks of antibiotic treatment for the mother, the breast milk culture was negative. Since breast milk culture was negative, breastfeeding was started again.

We questioned the mother again. We asked if she had had any contact with eggs or chicken. She said there were cracks in her breasts after breastfeeding. She also tried to heal these cracks on her own by spreading raw egg on her breasts.

\section{DISCUSSION}

We described here a rare case of Salmonella enteritidis late-onset newborn sepsis due to horizontal transmission of the causative agent through not properly handled breast milk. The value of this report is that the same strain of bacteria was isolated in the maternal milk as well as in the infant blood culture, and thereby the importance of sterile procedures is stressed while breastfeeding and expressing breast milk. Breastfeeding is very important for infant feeding. In practice, breast milk is not sterile. Mostly, bacterial flora (alpha hemolytic streptococci, diphtheroid bacilli, S. epidermidis, etc.) found in the mother's skin are transmitted to the baby with the mother's milk ${ }^{[3-}$

5]. Even if the mother has an infectious agent, it is recommended to continue breastfeeding in the baby's diet, except if the mother is HIV-positive. However, some pathogenic microorganisms have been shown to infect newborn infants as well as breast milk (Table 2). Examples reported include the Hepatitis B virus, HIV, Staphylococcus aureus, Mycobacterium tuberculosis, Candida and Cryptococcus species ${ }^{[3]}$. Salmonella transmission by breastfeeding has rarely been reported. Infection with Salmonella for babies with weak immunity is both dangerous and important.

Non-typhoidal Salmonella (NTS) is one of the food-borne microbes. NTS infections cause serious health problems, especially in children under two years of age. NTS can lead to serious infections, such as bacteremia, septic arthritis, meningitis and pneumonia if it is transmitted to infants. In the literature, the number of studies reporting NTS transmission by breast milk is quite limited. In 2003, for the first time, Qutishat et al. reported the transmission of Salmonella to infant twins with breast milk. It is clear that breast milk should be obtained hygienically. The inadequacy of the mother's hygiene plays an important role in the transmission of pathogenic microorganisms in breast milk. However, it has been reported that there may be external sources, such as milk pumps and water, in the transmission of breast milk Salmonella ${ }^{[11]}$. The growth of the same bacteria in the mother's milk and the infant's blood indicates that the mother's milk is undoubtedly the source. This shows the importance of mothers training in breastfeeding. We think that every woman who has given birth should be educated about obtaining safe milk.

We believe that the bacterial transmission to the infant occurred at home after the mother was discharged, because in the detailed obtained anamnesis, the mother explained that she had cracked nipples after breastfeeding and spread raw eggs over these cracks. We think that the NTS was transmitted to the patient by this egg. 
Table 2. Microorganisms reported in the literature to infect breast milk

\begin{tabular}{|c|c|c|c|c|}
\hline Author & Year & Microorganisms & Diagnosis & Therapy \\
\hline Mann et al. ${ }^{[4]}$ & 2018 & $\begin{array}{l}\text { Yellow fever transmission } \\
\text { from breastfeeding was } \\
\text { shown. }\end{array}$ & Mixed as it is a systematic review & No data \\
\hline Louvanto et al.. ${ }^{[5]}$ & 2017 & $\begin{array}{l}\text { Human Papillomavirus } \\
\text { transmission in breast } \\
\text { milk was shown. }\end{array}$ & $\begin{array}{l}\text { Mothers took the milk samples } \\
\text { manually on the } 3 \text {. day and } 2 ., 6 \text {. } \\
\text { and } 12 \text {. months. Cervical and/or } \\
\text { oral samples were obtained from } \\
\text { all family members. HPV testing } \\
\text { was performed using the nested } \\
\text { polymerase chain reaction. }\end{array}$ & No data \\
\hline Slyker et al. ${ }^{[6]}$ & 2017 & $\begin{array}{l}\text { Cytomegalovirus } \\
\text { transmission in } \\
\text { breastfeeding was shown. }\end{array}$ & $\begin{array}{l}\text { Cytomegalovirus viral loads were } \\
\text { measured from infant's plasma and } \\
\text { breast milk. }\end{array}$ & $\begin{array}{l}\text { Antenatal zidovudine } \\
\text { plus nevirapine }\end{array}$ \\
\hline Chen et al. ${ }^{[7]}$ & 2016 & $\begin{array}{l}\text { Breastfeeding-related } S . \\
\text { aureus was shown. }\end{array}$ & $\begin{array}{l}\text { Stool samples and breast milk } \\
\text { samples of babies with diarrhea were } \\
\text { cultured. Staphylococcus aureus grew } \\
\text { in six specimens. The homology and } \\
\text { molecular properties of the isolated } \\
\text { strains (PFGE), spa typing, pulse field } \\
\text { gel electrophoresis were tested. }\end{array}$ & No data \\
\hline Celebi et al. ${ }^{[8]}$ & 2007 & $\begin{array}{l}\text { Asymptomatic Brucella } \\
\text { transmission with breast- } \\
\text { milk }\end{array}$ & $\begin{array}{l}\text { A family that contained four } \\
\text { members was screened with physical } \\
\text { examination, wright test, blood } \\
\text { cultures. Brucella melitensis biovar } 3 \\
\text { was isolated from breast milk and } \\
\text { from all blood cultures. }\end{array}$ & $\begin{array}{l}\text { A combination } \\
\text { of rifampicin plus } \\
\text { doxcycline was } \\
\text { given for } 6 \text { weeks to } \\
\text { mother. }\end{array}$ \\
\hline Grischott et al. ${ }^{[9]}$ & 2016 & $\begin{array}{l}\text { Breastfeeding-related Zika } \\
\text { virus infection. }\end{array}$ & $\begin{array}{l}\text { This research is a systematic review. } \\
\text { Zika virus RNA has been reported } \\
\text { to be detected in the amniotic } \\
\text { fluid, breast milk, seminal fluid, } \\
\text { saliva, urine, and blood. Semen and } \\
\text { blood products have proven to be } \\
\text { infectious. }\end{array}$ & No data \\
\hline Afolabi et al. ${ }^{[10]}$ & 2018 & $\begin{array}{l}\text { Breastfeeding related HIV- } \\
1 \text { transmission. }\end{array}$ & $\begin{array}{l}\text { HIV RNA and CD4 levels were } \\
\text { measured in } 60 \text { subjects. }\end{array}$ & $\begin{array}{l}\text { Nevirapine, } \\
\text { azidotimidin and } \\
\text { lamivudine }\end{array}$ \\
\hline Qutishat et al. ${ }^{[11]}$ & 2003 & $\begin{array}{l}\text { Salmonella typhimurium } \\
\text { transmission in breast } \\
\text { milk was shown. }\end{array}$ & $\begin{array}{l}\text { Salmonella group D1 was isolated } \\
\text { from blood and cerebrospinal fluid } \\
\text { and breast milk samples. }\end{array}$ & $\begin{array}{l}\text { The baby was } \\
\text { treated with } \\
\text { cefotaxime for } 21 \\
\text { days. }\end{array}$ \\
\hline
\end{tabular}

S. enteritidis is an important bacteria that is easily transmitted from chicken and eggs ${ }^{[12]}$. Therefore, the cause of sepsis might be the mother who colonized the breast milk with laying egg on her cracked nipples and breastfed her own infant from this breast. Salmonella is a bacterium usually known for causing bowel infections. However, the cause of sepsis may be related to the infant's inadequate immune system ${ }^{[13]}$.
The other important aspect of this case is its rapid recovery with treatment. In this case, sepsis was recognized very quickly since the patient had decreased milk intake, hypotonic, fever and diarrhea. Immediately, antibiotics were started, and the patient quickly recovered. Blood culture was positive for Salmonella only after 48 hours. This shows the importance of early treatment in patients with sepsis. 
Breastfeeding is very important for the newborn infant. However, breast milk should be obtained in clean and hygienic conditions. Breast milk can be a serious source of bacteria if mothers are breastfeeding in unhygienic conditions.

\section{CONFLICT of INTEREST}

Authors have no competing interests to disclose.

\section{AUTHORSHIP CONTRIBUTIONS}

Concept/Design: MK, MK

Analysis/Interpretation: HAT, IC

Data Acquisition: ZS, HAT, IC

Writting: MK, HAT, MK

Revision and Correction: HAT, MK, MK

Final Approval: HAT, MK, MK

\section{REFERENCES}

1. Li $Y$, Jaykus $L A$, Cates $S$, Wohlgenant $K$, Chen $X$, Fraser $A M$. Hygienic conditions in child-care facilities in North Carolina and South Carolina: an integrated microbial and observational study. Am J Infect Control 2014;42(7):781-6.

2. Revathi G, Mahajan R, Faridi MMA, Kumar A, Talwar $V$. Transmission of lethal Salmonella senftenberg from mother's breast-milk to her baby. Ann Trop Paediatr 1995; 15(2):159-61.

3. Macdonald NE. Maternal Infectious diseases, antimicrobial therapy or immunizations: very few contraindications to breastfeeding. Can I Infect Dis Med Microbiol 2006;17(5):270-2

4. Mann TZ, Haddad LB, Williams TR, Hills SL, Read JS, Dee $D L$, et al. Breast milk transmission of flaviviruses in the context of Zika virus: A systematic review. Paediatr Perinat Epidemiol 2018;32(4):358-68.

5. Louvanto $K$, Sarkola $M$, Rintala $M$, Syrjänen $K$, Grenman S, Syrjänen S. Breast milk is a potential vehicle for Human Papillomavirus transmission to oral mucosa of the spouse. Pediatr Infect Dis J 2017;36(7):627-30.

6. Slyker JA, Richardson B, Chung MH, Atkinson C, Ásbjörnsdóttir KH, Lehman DA, et al. Maternal highly active antiretroviral therapy reduces vertical Cytomegalovirus transmission but does not reduce breast milk Cytomegalovirus levels. AIDS Res Hum Retroviruses 2017;33(4):332-8.
7. Chen $Z$, Pan $W-G$, Xian WY, Cheng $H$, Zheng J-X, Hu Q-H, et al. Identification of infantile diarrhea caused by breast milk-transmitted Staphylococcus aureus infection. Curr Microbiol 2016;73(4):498-502.

8. Celebi G, Külah C, Kiliç S, Ustündağ G. Asymptomatic Brucella bacteraemia and isolation of Brucella melitensis biovar 3 from human breast milk. Scand I Infect Dis 2007;39(3):205-8.

9. Grischott $F$, Puhan $M$, Hatz C, Schlagenhauf P. Non-vector-borne transmission of Zika virus: A systematic review. Travel Med Infect Dis 2016;14(4):313-30.

10. Afolabi AY, Bakarey AS, Kolawole OE, Kola OJ. Investigation of mother-to-child transmission of HIV in pregnancy and among HIV-exposed infants accessing care at a PMTCT clinic in southwest Nigeria. I Immunoassay Immunochem 2018;39(4):403-15.

11. Qutaishat SS, Stemper ME, Spencer SK, Borchardt MA, Opitz JC, Monson TA, et al. Transmission of Salmonella enterica serotype typhimurium DT104 to infants through mother's breast milk. Pediatrics 2003;111(6 Pt 1):1442-6.

12. Chen J, Thesmar HS. Populations of Salmonella Enteritidis in Artificially Inoculated Chicken Eggs as Influenced by the Temperatures under Which Eggs Might Be Held from the Day of Lay until the Day of Processing. I Food Prot 2008; 71(10):2073-7.

13. Saravanan S, Purushothaman V, Murthy TRGK, Sukumar K, Srinivasan P, Gowthaman V, et al. Molecular epidemiology of nontyphoidal salmonella in poultry and poultry products in India: Implications for Human Health. Indian J Microbiol 2015;55(3):319-26.

\section{Address for Correspondence/Yazıșma Adresi}

Dr. Öğr. Üyesi Meltem KARABAY

Sakarya Eğitim ve Araștırma Hastanesi,

Çocuk Sağlığı ve Hastalıkları Anabilim Dalı,

Neoanatoloji Kliniŏi,

Sakarya-Türkiye

E-mail: agah.terzi@yahoo.com 